\title{
Production of cellulases through Solid State Fermentation (SSF) using agricultural waste biomass as solid substrates by Aspergillus niger
}

\author{
P. R. Kakde ${ }^{1}$, S. C. Aithal ${ }^{2 *}$ \\ ${ }^{1,2^{*}}$ Microbiology research centre, Dept. of Microbiology, Dnyanopasak College, Parbhani-431 401, Maharashtra, India. \\ *Corresponding Author: shiva.aithal@rediffmail.com
}

Available online at: www.isroset.org

Accepted: 18/Aug/2018, Online: 30/Aug/ 2018

\begin{abstract}
A study was conducted to appraise the potential of using agricultural lignocellulosic wastes for cellulase production by Aspergillus niger through Solid State Fermentation (SSF) technique. In the present study, agricultural waste biomass like Banana Peels (BP), Cotton Stalks and Leaves (CSL), Green Pea Shell (GPS), Soybean Leaves and Stalks (SLS), Sugarcane Bagasse (SB), Tur Leaves (TL) and Wheat Straw (WS) were used as substrates. These untreated substrates were found to be well suited for the organism's growth, producing good amounts of cellulases. It was observed that GPS, SB, TL, BP served as better substrates than others for fungal growth. These four substrates were thus selected for cellulase production study. They were supplemented with nitrogen source in the form peptone, casein, sodium nitrate and urea. This comparative study for the cellulase production via SSF indicated that cellulase activity produced by A. niger was higher in GPS supplemented with casein at $\mathrm{p}^{\mathrm{H}} 5$ and incubation temperature of $50^{\circ} \mathrm{C}$ when incubated for $60 \mathrm{~min}$.
\end{abstract}

Keywords- Aspergillus niger, Agricultural waste biomass, Cellulases, Solid State Fermentation (SSF)

\section{INTRODUCTION}

Sustainability, abundant availability at almost zero cost of agricultural waste biomass has led to increased interest in their bioconversion into value-added products (including biofuels) [1,2,3]. Lignocelluloses are the structural polysaccharides of plants that composed cellulose as their major component followed by hemicellulose and lignin [4,5]. Complete hydrolysis of cellulose into basic subunit, glucose requires synergistic action of complete cellulase system encompassing three enzymes endoglucanases (EC 3.2.1.4), exoglucanases (cellobiohydrolases; EC 3.2.1.91) and $\beta$ glucosidases (EC 3.2.1.21) [6,7,8]. Several microorganisms have found to be capable of producing cellulases including bacteria, actinomycetes and fungi but later are of great interest as they excrete copious amounts of cellulases and hemicellulases enzymes extracellularly [9]. Commercially Trichoderma reesei is popular fungal strain for cellulase production as they produce high amount of both endo- and exo-glucanases, but does not produce sufficient amount of $\beta$ glucosidases [10,7,11]. And therefore Aspergillus strains have been recently exploited considering its ability to produce all the three components of cellulase [12].

Although cellulase is produced via submerged fermentation $(\mathrm{SmF})$ commercially, solid state fermentation (SSF) is mostly employed because of its advantages over prior as it is cheap, requires lower energy, a simple fermentation medium, has high enzyme yield, superior productivity, an easy control of bacterial contamination and lower costs of downstream processing $[13,14,15]$. The present work aims at studying the potential of using various agricultural waste biomass for growth of A. niger as well as cellulase production.

Thus the present work focuses on the evaluation of various agricultural wastes for their ability to support growth of $A$. niger as well as production of cellulases by them via solid state fermentation.

Section I of the paper contains brief introduction of the topic, Section II contain the methodology used, Section III is about results and discussion and Section IV concludes research work with future directions.

\section{MethodologY}

\section{Microorganism}

A. niger used in the present study was isolated from garden soil of DSM College, Parbhani and maintained on a Potato Dextrose Agar (PDA) as slants.

\section{Inoculum preparation}

Inoculum in the form of spore suspension used in the present study was prepared by adding $10 \mathrm{ml}$ of acetate buffer of $\mathrm{P}^{\mathrm{H}} 4$ containing few drops of tween 80 .

\section{Substrate Preparation}

Various agro-waste residues like Banana Peels (BP), Cotton Stalks and Leaves (CSL), Green Pea Shell (GPS), Soybean Leaves and Stalks (SLS), Sugarcane Bagasse (SB), Tur Leaves (TL) and Wheat Straw (WS) were collected locally. These were sun dried separately till moisture was completely removed, before being finely crushed into powder using 
kitchen blender. Powder was then stored in air tight containers until further use.

\section{Qualitative growth analysis of $A$. niger on different} agricultural wastes

Each substrate (BP, CSL, GPS, SLS, SB, TL and WS) was taken $10 \mathrm{~g}$ into the separate flasks and inoculated with $3 \mathrm{ml}$ inoculum. Media was then poured into Petri dishes and incubated at $30^{\circ} \mathrm{C}$ for 12 days under static conditions.

\section{Cellulase production}

After 12 days four substrates exhibiting maximum A. niger growth were selected and supplemented with nitrogen sources such as peptone, casein, urea, sodium nitrate in order to find best optimized media in terms of nitrogen source for A. niger growth and enzyme production. 10 gram of GPS, $\mathrm{SB}, \mathrm{TL}$ and $\mathrm{BP}$ powder was taken into the respective flasks and moistened with $4 \mathrm{ml}$ distilled water. Flasks were autoclaved at $121^{\circ} \mathrm{C}$ for 20 minutes. After cooling, media was poured into sterile Petri plate. It was then inoculated with $2 \mathrm{ml}$ inoculum followed by addition of $3 \mathrm{ml}$ of $2 \%$ of each of the selected sterile nitrogen source. Plates were incubated at $30^{\circ} \mathrm{C}$ for 10 days under static conditions.

\section{Enzyme extraction}

After 10 days of fermentation the content of each dish was transferred into Erlenmeyer flasks containing $50 \mathrm{ml}$ of acetate buffer $\left(0.1 \mathrm{M}, \mathrm{P}^{\mathrm{H}} 4.8\right)$ and then stirred in a rotary shaker (150 rpm, $30 \mathrm{~min}$ at room temperature). The contents of the flasks were then filtered through a metallic sieve and filtrate was centrifuged at $8000 \mathrm{rpm}$ for $15 \mathrm{~min}$. The supernatant was collected as crude enzyme extract for the determination of cellulolytic activities.

\section{Enzyme Assay and Enzyme Unit}

Filter paper assay (FPase) method: Whatman No. 1 filter paper strips of $50 \mathrm{mg}(1 \times 6 \mathrm{~cm})$ were inserted into a test tube containing of $1 \mathrm{ml}$ of $0.05 \mathrm{M}$ citrate buffer (pH 4.8) in which $1 \mathrm{ml}$ of crude enzyme was added. The test tubes were incubated in a water bath for $60 \mathrm{~min}$ at $50^{\circ} \mathrm{C}$. After incubation, the reaction was terminated by the addition of 3 $\mathrm{ml}$ of dinitrosalicylic acid (DNS) reagent. The tubes were boiled for $15 \mathrm{~min}$ in a boiling water bath and cooled. After cooling to room temperature, optical density (OD) was measured at $540 \mathrm{~nm}$. The amount of reducing sugars produced was calculated from a glucose standard curve [16].

One filter paper unit (FPU) was defined as the amount of enzyme releasing 1 mole of reducing sugar from filter paper per $\mathrm{ml} / \mathrm{min}$.

\section{Evaluation of Enzyme Activity at Different Conditions of} $\mathbf{P}^{\mathrm{H}}$, Temperature and Incubation time

Crude enzyme extract from substrate supplemented with nitrogen source exhibiting maximum enzyme activity was selected for further study. Its activity was checked at various parameters like $\mathrm{pH}$, temperature and incubation time.

\section{Effect of different $\mathbf{P}^{\mathrm{H}}$}

In this experiment, $1 \mathrm{ml}$ of $0.05 \mathrm{M}$ citrate buffer of varying $\mathrm{P}^{\mathrm{H}} 3.0,4.0,5.0$ and 6.0 was used and cellulase activity was calculated by FPase assay.

\section{Effect of different temperature}

To evaluate cellulase activity at different temperature, extracted crude cellulase was incubated at various assay incubation temperatures of $30^{\circ}, 40^{\circ}, 50^{\circ}$ and $60^{\circ}$.

\section{Effect of different assay incubation time}

In order to check effect of varying incubation time on cellulase activity, it was incubated for 60, 120, 180, and 240 min. and FPase activity was evaluated.

\section{RESUlTS AND DISCUSSION}

Qualitative growth analysis of $A$. niger on different agricultural wastes

Table 1: Qualitative growth analysis of $A$. niger on different agricultural wastes

\begin{tabular}{|c|c|c|c|c|c|c|}
\hline \multirow{2}{*}{ Substrate } & \multicolumn{7}{|c|}{ Incubation days } \\
\cline { 2 - 7 } & $2^{\text {nd }}$ & $4^{\text {th }}$ & $6^{\text {th }}$ & $8^{\text {th }}$ & $10^{\text {th }}$ & $12^{\text {th }}$ \\
\hline SB & - & + & ++ & ++ & +++ & +++ \\
\hline GPS & - & - & + & + & ++ & +++ \\
\hline CSL & - & - & - & + & + & ++ \\
\hline TL & - & + & + & ++ & ++ & +++ \\
\hline SLS & - & - & - & + & + & ++ \\
\hline BP & - & + & ++ & ++ & +++ & +++ \\
\hline WS & - & - & - & - & - & - \\
\hline
\end{tabular}

(+) Moderate growth; (++) Good growth; (+++) Very good growth.

The effect of eight different agricultural wastes viz., BP, CSL, GPS, SLS, SB, TL and WS on the qualitative growth of A. niger, were studied and the results are given in Table 1. Less growth on nearly all substrate was recorded at initial period of incubation. On further incubation more growth of A. niger were recorded on BP, GPS, SB and TL. Comparatively less growth recorded on CSL, SLS and no growth was recorded on WS.

And therefore, substrates showing maximum growth of fungi BP, TL, SB and GPS were selected for further study.

\section{Cellulase production on nitrogen supplemented media}

The result of this investigation shows that the organic nitrogen sources, peptone and casein supports better biomass of $A$. niger yield as compared to the inorganic nitrogen substrates tested (Table 2).

FPase activity of the respective samples is as mentioned in fig 1 . Highest FPase activity i.e. $0.34 \mathrm{IU} / \mathrm{ml}$ is produced by GPS on casein nitrogen source. While on peptone, urea, and sodium nitrate it is found to be $0.10,0.15,0.06$ respectively. TL shows maximum enzyme production on sodium nitrate, 
$0.25 \mathrm{IU} / \mathrm{ml}$. SB produced highest cellulose on peptone i.e.0.13 and $0.009,0.022,0.005$ on casein, urea, and sodium nitrate respectively. Compared to other nitrogen sources, sodium nitrate is found to be less efficient as nitrogen source for cellulase production.

Table 2: Comparative analysis of $A$. niger growth on agricultural substrate

\begin{tabular}{|c|c|c|c|c|c|c|}
\hline \multirow[t]{2}{*}{ Substrate } & \multirow{2}{*}{$\begin{array}{l}\text { Nitrogen } \\
\text { source }\end{array}$} & \multicolumn{5}{|c|}{ Incubation days } \\
\hline & & $2^{\text {nd }}$ & $4^{\text {th }}$ & $6^{\text {th }}$ & $8^{\text {th }}$ & $10^{t h}$ \\
\hline \multirow[b]{4}{*}{ SB } & Peptone & - & ++ & ++ & +++ & +++ \\
\hline & Casein & - & + & + & ++ & ++ \\
\hline & Urea & - & ++ & +++ & +++ & +++ \\
\hline & $\begin{array}{l}\text { Sodium } \\
\text { nitrate }\end{array}$ & - & - & + & + & + \\
\hline \multirow{4}{*}{$\mathrm{BP}$} & Peptone & - & - & - & + & + \\
\hline & Casein & - & - & - & + & + \\
\hline & Urea & - & ++ & ++ & ++ & ++ \\
\hline & $\begin{array}{l}\text { Sodium } \\
\text { nitrate }\end{array}$ & - & - & - & - & - \\
\hline \multirow{4}{*}{ GPS } & Peptone & - & ++ & ++ & +++ & +++ \\
\hline & Casein & - & ++ & ++ & +++ & +++ \\
\hline & Urea & - & + & + & ++ & ++ \\
\hline & $\begin{array}{l}\text { Sodium } \\
\text { nitrate }\end{array}$ & - & - & - & - & + \\
\hline \multirow{4}{*}{ TL } & Peptone & - & + & ++ & ++ & ++ \\
\hline & Casein & - & + & ++ & ++ & ++ \\
\hline & Urea & - & +++ & +++ & +++ & +++ \\
\hline & $\begin{array}{l}\text { Sodium } \\
\text { nitrate }\end{array}$ & - & - & + & ++ & ++ \\
\hline
\end{tabular}

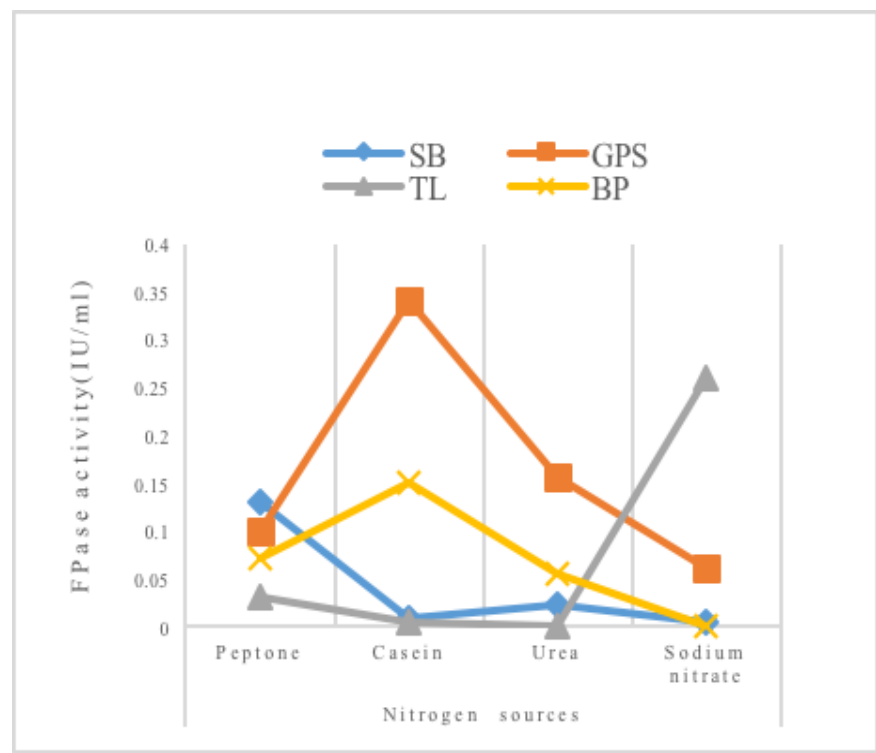

Figure 1 Cellulase activity using A. niger on nitrogen supplemented media.

Evaluation of Enzyme Activity at Different Conditions of $\mathbf{P}^{\mathrm{H}}$, Temperature and incubation time

Enzyme characterization of enzyme is necessary to understand their behaviour at various physical and chemical parameters. In this work, maximum enzyme activity was obtained of GPS on casein nitrogen source. Therefore, crude enzyme extracted from it was subjected to study at various $\mathrm{pH}$, temperature and incubation time.

\section{Effect of $\mathbf{P}^{\mathrm{H}}$}

The $\mathrm{P}^{\mathrm{H}}$ of a medium plays an important role in the production of a cellulase that uses natural catalyst i.e fungi. Cellulase activity of GPS from casein as nitrogen source was evaluated at $\mathrm{P}^{\mathrm{H}}$ 3.0, 4.0, 5.0 and 6.0. It is inferred in Fig. 2 that $\mathrm{P}^{\mathrm{H}} 5$ is found to be the optimal $\mathrm{P}^{\mathrm{H}}$ for cellulase

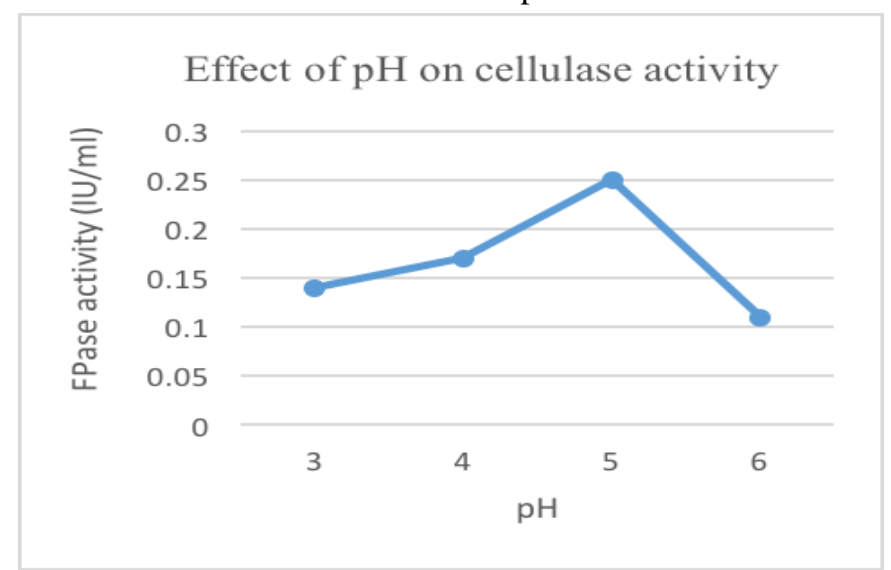

production by $A$. niger where cellulase activity is maximum (0.25 IU/ml).

Figure 2 Cellulase activity by A. niger measured at different assay $P^{H}$ using GPS (Casein as nitrogen source) as substrate.

\section{Effect of temperature}

In addition to $\mathrm{P}^{\mathrm{H}}$, the temperature is the second important parameter that affects the activity of an enzyme. Maximum enzyme activity by $A$. niger on GPS on casein nitrogen source as substrate is found at $50^{\circ} \mathrm{C}$. FPase activity at $50^{\circ} \mathrm{C}$ is $0.35 \mathrm{IU} / \mathrm{ml}$. Incubation at higher temperature reflected lower enzyme activity.

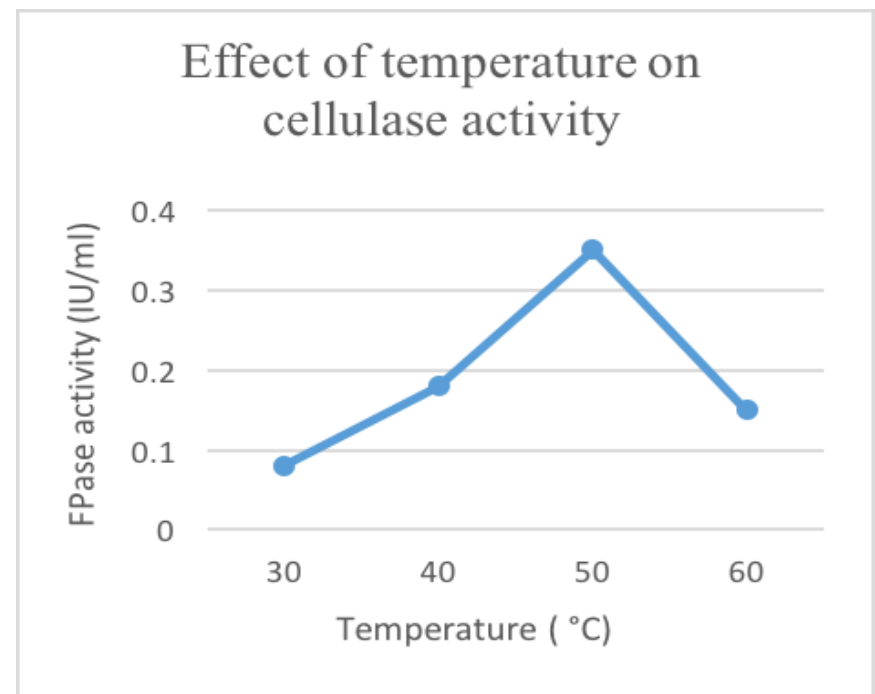

Figure 3 Cellulase activity by A. niger measured at different assay temperature using GPS (Casein as nitrogen source) as substrate. 


\section{Effect of incubation time}

The effect of incubation time is studied to examine the maximum activity of cellulase. As shown in figure 4 , the highest $(0.35 \mathrm{IU} / \mathrm{ml})$ enzyme activity of $A$. niger on GPS (Casein) is found at $60 \mathrm{~min}$. later on as the incubation time increased enzyme activity is found to be decreased.

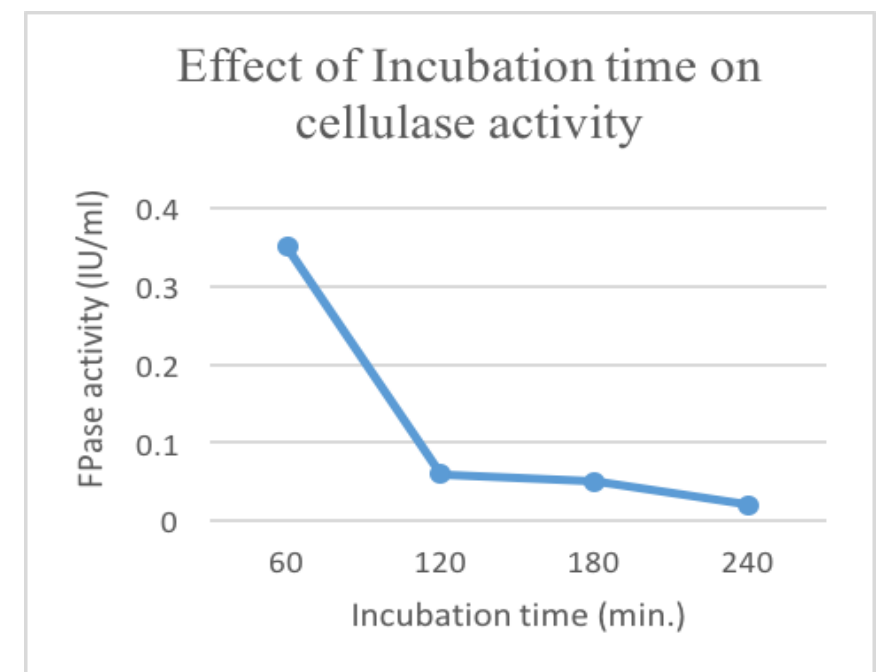

Figure 4 Cellulase activity by A. niger measured at different assay incubation time using GPS (Casein as nitrogen source) as substrate.

\section{CONCLUSION AND FUtURE SCOPE}

Successful attempts have been made to make use of various agro-waste residues as substrates for the production of complete cellulase complex by A. niger via solid state fermentation, with a view to developing a low cost production system.

This study establishes that agricultural waste biomass could serve as an ideal substrate for production of cellulases. That will assuage both environmental and economic crisis along with reliving waste-management problem.

\section{REFERENCES}

[1] A. Roedl, "Production and energetic utilization of wood from short rotation coppice-a life cycle assessment", Int J Life Cycle Assess, Vol.15, pp.567-578, 2010.

[2] W. O. S. Doherty, P. Mousavioun and C. M. Fellows, "Valueadding to cellulosic ethanol:lignin polymers", Ind Crops Prod, Vol. 33, pp. 259-276, 2011.

[3] P. Gallezot, "Conversion of biomass to selected chemical products", Chem Soc Rev, Vol. 41, pp.1538-1558, 2012.

[4] L. Chang, M. Ding, L. Bao et al, "Characterization of a bifunctional xylanase/ endoglucanase from yak rumen microorganisms", Appl Microbiol Biotechnol, Vol. 90, pp.1933-1942, 2011.

[5] S. Park, C. Ransom, C. Mei et al, "The quest for alternatives to microbial cellulase mix production: corn stover-produced heterologous multicellulases readily deconstruct lignocellulosic biomass into fermentable sugars", J Chem Technol Biotechnol Vol. 86, Issue. 5 pp.633-641, 2011.

[6] M.A. Milala, A. Shugaba, A. Gidado, A.C. Ene, J.A. Wafer, "Studies on the use of agricultural wastes for cellulase enzyme productions by Aspergillus niger”, Res. J. Agric. Biol. Sci. Vol. 1, pp. 325-328, 2005.

[7] N. Bansal, R. Tewari, J.K. Gupta, S.K. Soni, R. Soni, "A novel strain of Aspergillus niger producing a cocktail of industrial depolymerising enzymes for the production of second generation biofuels", BioRes. Vol. 6, pp. 552-569, 2011.

[8] D. Deswal, Y.P. Khasa, R.C. Kuhad, "Optimization of cellulase production by a brown rot fungus Fomitopsis sp. RCK2010 under solid state fermentation", Bioresour. Technol. Vol. 102, pp. 60656072, 2011.

[9] M. Bollok, K. Reczey, "Cellulase enzyme production by various fungal strains on different carbon sources", Acta Alimentaria. Vol. 29, pp. 155-168, 2005.

[10] A. Miettinen-Oinnonen, P. Suominen, "Enhanced production of Trichoderma reesei endoglucanses and use of the new cellulase preparations in producing the stone washed effect on denim fabrics", Appl. Environ. Microbiol. Vol. 68, pp. 3956-3964, 2002.

[11] T. Juhasz, K. Kozma, Z. Szengyel, K. Reczey, "Production of beta glucosidase in mixed culture of Aspergillus niger BKMF 1305 and Trichoderma reesei RUT-C30", Food Technol. Biotechnol. Vol. 41, pp. 49-53, 2003.

[12] N. Bansal, R. Tewari, R. Soni, S. K. Soni, "Production of cellulases from Aspergillus niger NS-2 in solid state fermentation", Waste Management, Vol. 32: pp. 1341-1346, 2012.

[13] A. Pandey, "Solid-State Fermentation". Wiley Eastern Limited, New Delhi, pp. 12-17, 1994.

[14] C. Krishna "Solid-state fermentation systems - An Overview", Crit. Rev. Biotechnol. Vol. 25, pp. 1-30, 2005.

[15] A.A Sherief, A.B. El-Tanash, N. Atia, "Cellulase production by Aspergillus fumigates on mixed substrate of rice straw and wheat bran", Res. J. Microbiol. Vol. 5, pp. 199-211, 2010.

[16] T.K. Ghose, "Measurement of cellulase activities", Pure Applied Chemistry, Vol. 59, pp. 257-268, 1987.

\section{AUTHORS PROFILE}

P. R. Kakde is a research scholar at the Microbiology Research Centre, Dept. of Microbiology, Dnyanopasak Shikshan Mandal's College of Arts, Commerce and Science, Parbhani (M.S.).

Dr. S. C. Aithal is serving as an Assistant Professor in Microbiology at Undergraduate and postgraduate level since 1993 in Dnyanopasak Shikshan Mandal's College of Arts, Commerce and Science, Parbhani (M.S.).
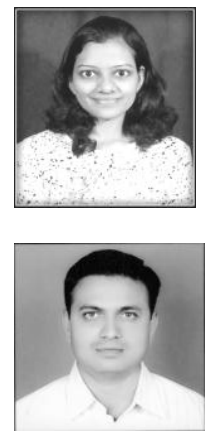